\title{
INCOMPATIBILITY STUDIES IN THE GENUS GIBASIS SECTION HETEROBASIS D. R. HUNT (COMMELINACEAE)
}

\author{
SIMON OWENS \\ Jodrell Laboratory, Royal Botanic Gardens, Kew, Richmond, Surrey TW9 3DS \\ Received 1.ix.76
}

\section{SUMMARY}

Two species in the genus Gibasis section Heterobasis have been exarnined to confirm their incompatibility reaction and to determine its genetic control. Five individuals of $G$. oaxacana $(2 x=16)$ from a single Mexican population (Hunt 8175) were found to be self-incompatible. Three accessions of tetraploid cytotypes $(4 x=32$; Hunt 7012, 7072 and 7160) and two accessions of hexaploid cytotypes ( $6 x=48$; Jones 72 and Bacigallipo 711257) of Gibasis geniculata were found to be self-compatible. Analysis of an $F_{1}$ population raised from an intercross between two heterozygous genotypes of $G$. oaxacana was consistent with an hypothesis that self-incompatibility is controlled by a single multiallelic gene acting gametophytically in the pollen.

Unilateral incompatibility was found in crosses between $G$. oaxacana and G. geniculata.

\section{InTRODUGTION}

THE purpose of this study is to confirm the existence of self-incompatibility in Gibasis oaxacana and to determine its genetic control. An attempt is made to demonstrate the relationship between species in the section Heterobasis of the genus particularly with regard to the evolution of the breeding system.

For several years at Kew considerable effort has been focused on the cytology and cytotaxonomy of the Tradescantia family, Commelinaceae (Jones and Colden, 1968; Jones, Colden and Hunt, 1969; Jones and Kukkonen, 1971; Jones and Jopling, 1972; Jones, Papes and Hunt, 1975; Jones, 1974, and unpub.). Not surprisingly these results have often influenced taxonomic decisions (e.g. Hunt, 1975) as well as giving support to particular taxonomic treatments. Chromosome data for example supports the taxonomic treatment of Rohweder (1956) in separating the genus Gibasis (with at least 14 species) from Tradescantia. The species of the genus Gibasis $(x=4,5)$ examined by Jones and Jopling (1972) were unlike Tradescantia sensu stricto in basic number and all, apart from diploid $G$. pulchella $(2 n=10)$, had asymmetric chromosome complements.

Gibasis still embraces a remarkable variation in chromosome number, size and shape but it can be partitioned into a number of groups on the basis of karyotype (Jones, Papes and Hunt, 1975) and has been divided broadly into two sections, Gibasis aud Heterobasis (Hunt, I975). Heterobasis, the concern of this paper, includes two species both with relatively small asymmetric chromosomes and a basic number of $x=8$. G. oaxacana is selfincompatible and diploid $(2 x=16), G$. geniculata is highly self-fertile and two cytotypes have been found, viz. a tetraploid $(4 x=32)$ and a hexaploid $(6 x=48$; Jones, Colden and Hunt, 1969). 
Although self-incompatibility is widespread among species in the family (Owens, unpub.) attempts to discover its genetic control have been focused exclusively on North American species of Tradescantia. Anderson and Sax (1934) in an analysis based upon aceto-carmine smears of self- and crosspollinated styles in three Tradescantia species, viz. T. edwardsiana, T. gigantea and $\mathcal{T}$. humilis, decided that their results were in broad agreement with the oppositional factor hypothesis (incompatibility of the gemetophytic type). This conclusion received support from the work of Brewbaker (1957, 1967). The mature pollen grain of species in the genus Tradescantia is of the binucleate type (containing a single vegetative and a single undivided generative nucleus) and Brewbaker (l.c.) showed that the gametophytic type of incompatibility system was almost always associated with species which had mature binucleate pollen grains. The most complete analysis has been that of Annerstedt and Lundquist (1967) in T.paludosa. From a cross between two self-incompatible individuals obtained from different sources they raised an $F_{1}$ progeny of 200 plants. Ten were selected and intercrossed in a diallel together with the two parents, and fell into four intra-incompatible, intercompatible groups with respect to mating behaviour. All were reciprocally cross-compatible with the parents. The remaining $190 \mathrm{~F}_{1}$ individuals when crossed with selected singlc plants from each of the four groups were incompatible with one and totally compatible with the remaining three. From thcir results Anncrstedt and Lundquist (l.c.) favoured an interpretation involving a single multi-allelic locus operating gametophytically in the pollen. They could not, however, completely exclude an interpretation involving a second locus. This latter hypothesis appeared improbable since it required the genotype of the original parents to contain identical alleles at one locus, e.g. $S_{1.2} Z_{5.5}$ and $S_{3.4} Z_{5.5}$, a situation considered to be most unlikely when the sources of the original material were so different.

\section{Materials AND METHODS}

Plants of $G$. oaxacana and $G$. geniculata were taken from the collection of Commelinaceae held at Kew and are listed in table 1. All individuals were grown in greenhouses (temperature range $13-20^{\circ} \mathrm{C}$ ) in isolation from other Gibasis species during the winter period when insect pollinators were entirely absent.

\section{(i) Self-pollinations and intraspecific crosses}

Self- and cross-pollinations were made in the morning and for each pollination a single anther was removed from a flower with forceps and pollen dusted on to the recipient stigmas. (Flowers were not emasculated.) Each pollinated flower was marked by sticking a coloured adhesive spot to a petal and careful records were kept of each cross performed. An average of four (range 1-10) flowers was used to determine the compatibility of self- or crosspollinations. All pollinations were made during the period, 7th November 1972 to 23rd February 1973 inclusive.

Seed capsules from compatible pollinations could be scored after about 1 week from pollination. In incompatible matings flowers dropped from the inflorescence 3-4 days after pollination.

Controlled crosses between two self-incompatible genotypes of $G$. 
oaxacana $(8175 \mathrm{G} \times \mathrm{H})$ yielded 11 capsules and 63 seeds from which $31 \mathrm{~F}_{1}$ hybrid individuals were raised. $F_{1}$ plants were intercrossed in a $21 \times 21$ diallel.

Pollen tube growth was observed in stigmatic tissues by means of the callose fluorochrome reaction (de Grehu, 1968). For the assessment of pollen tube growth self-pollinations were performed and recorded as above.

\section{(ii) Interspecific crosses}

Although the flowers of $G$. geniculata open in the afternoon, crosspollinations are possible in the morning. Flowers which are due to open in an afternoon are recognisable in the morning because the white petals begin to show as the sepals separate. Flowers in this condition were forced open with forceps, emasculated and pollinated with pollen from G. oaxacana. Often pollen was already being shed in the closed bud (cleistogamy) but buds in this state were not used as females in crosses. Pollen from these buds was, however, used in the reciprocal with $G$. oaxacana. Seed set and pollen tube growth were observed and recorded as above.

\section{Results}

\section{(i) Self-pollination}

The results of selfing are shown in table 1. Three tetraploid accessions and two hexaploid accessions of $G$. geniculata were self-compatible. Five individuals of the diploid $G$. oaxacana collected from a single site were selfincompatible. Pollen tubes were inhibited in the stigmatic tissues (plate 1 (a) and (b)).

\section{(ii) $F_{1}$ analysis}

The mating behaviour of the $21 \mathrm{~F}_{1}$ progeny is shown in table 2. These plants were all self-incompatible (as their parents) and could be grouped into four intra-incompatible, inter-compatible classes containing three, seven, two and nine individuals respectively. The numbers of plants found in each of the four pollination groups do not differ significantly from the expected $1: 1: 1: 1$ ratio, since $\chi^{2}{ }_{(3)}=6 \cdot 238, P=0 \cdot 2-0 \cdot 1$. This latter result accords with an hypothesis that control is by a single multi-allelic locus operating gametophytically in the pollen. It also confirms that the parents were heterozygous for alleles at the $\mathrm{S}$ locus and had no alleles common.

\section{(iii) Interspecific crosses}

The results of the interspecific crosses (table 3) show that the pollen of the self-compatible $G$. geniculata is inhibited on the stigma of selfincompatible $G$. oaxacana while the reciprocal cross at either ploidy level is compatible. Inhibition of pollen tubes in incompatible matings is in the stigmatic tissue and is therefore the same site as for the self-incompatible reaction. In compatible matings pollen tube growth was normal although the rate of growth was not recorded. 
SIMON OWENS
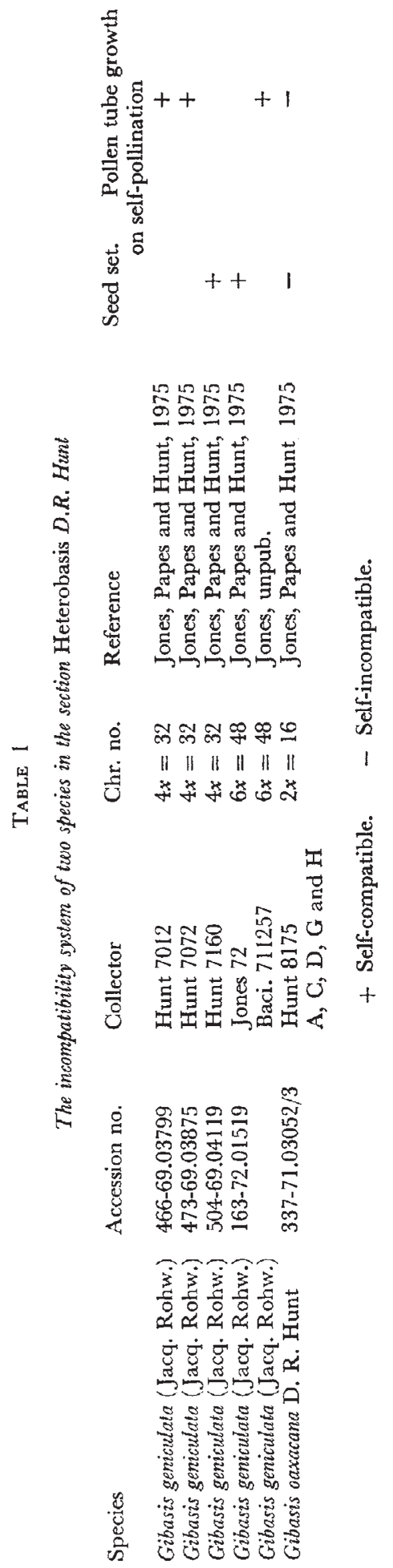

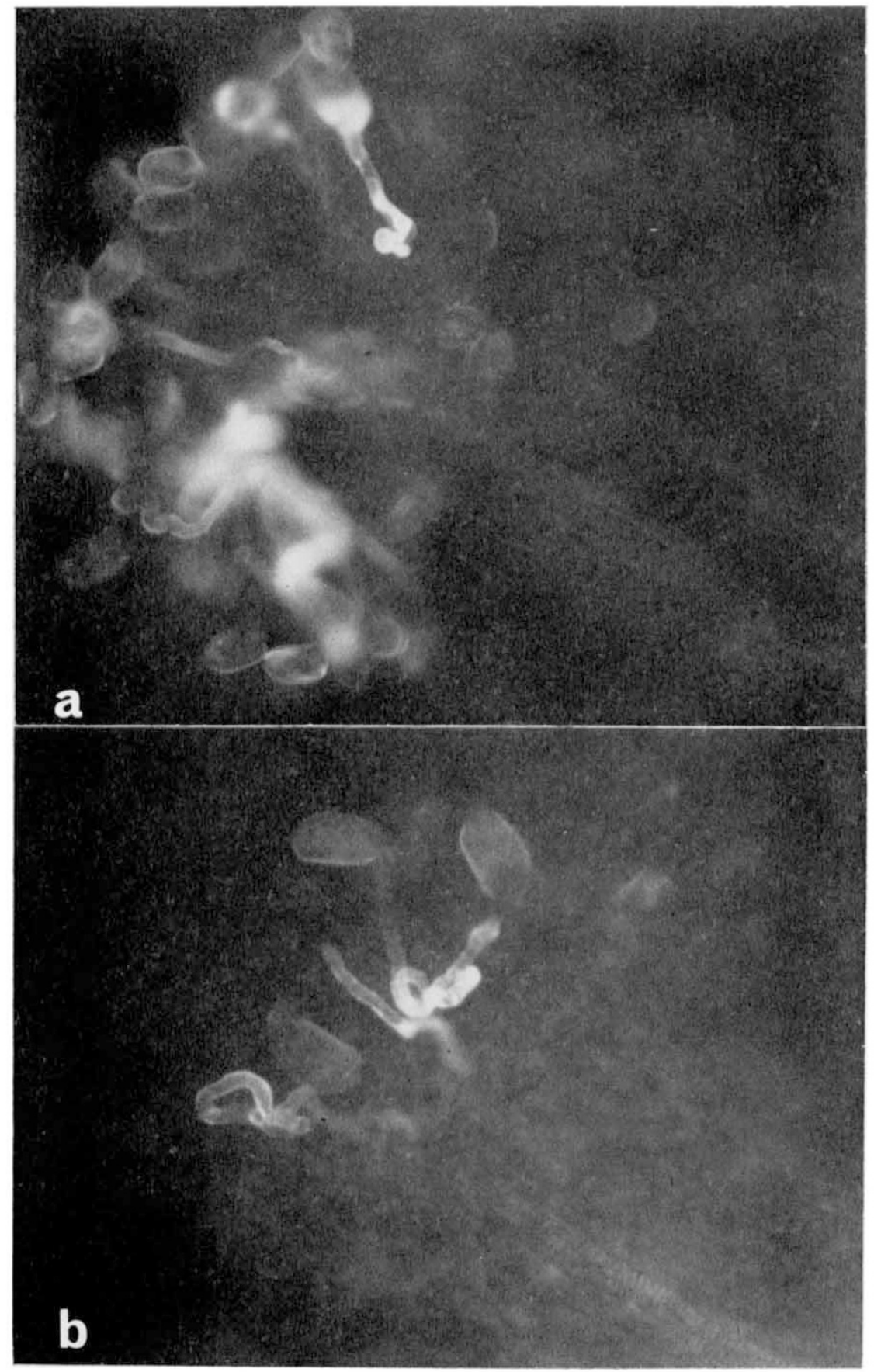

Plate $1(a)$ and (b). Inhibition of pollen tubes in the stigma tissues of G. oaxacana after self-pollination. 
TABLE 2

The results of intercrossing $21 F_{1}$ plants of $\mathrm{G}$. oaxacana arranged into four inter-compatible, intraincompatible groups, $A-D$



TABle 3

Pollen tube growth in crosses between G. oaxacana and G. geniculata

우 G. oaxacana G. geniculata $4 x$ G.geniculata $6 x$

G. oaxacana

G. geniculata $4 x$

G. geniculata $6 x$

$\begin{array}{ll}- & 0 \\ + & + \\ + & 0\end{array}$

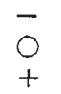

$+=$ Normal pollen tube growth in style.

- = Pollen tubes inhibited in top $1 \mathrm{~mm}$ of style.

$\mathrm{O}=$ Cross not made.

\section{Discussion}

Self-incompatiblity in $G$. oaxacana has been found to be controlled by a single locus gametophytic system, the most common system found in 
Angiosperm families. This result is in complete agreement with the interpretation of Annerstedt and Lundquist (1967) for diploid T. paludosa. The two genotypes of $G$. oaxacana which were crossed, $8175 \mathrm{G}$ and $\mathrm{H}$, may therefore be designated $S_{1.2}$ and $S_{3.4}$ respectively, the genotypes of the four $F_{1}$ classes being $\mathrm{S}_{1.3}, \mathrm{~S}_{2.3}, \mathrm{~S}_{1.4}$ and $\mathrm{S}_{2.4}$.

Unlike the species of Tradescantia investigated (Anderson and Sax, 1934; Annerstedt and Lundquist, 1967) the related polyploid G. geniculata is not self-incompatible. Indeed it is highly self-fertile. The results obtained from crosses between $G$. oaxacana and $G$. geniculata are those expected for crosses between self-incompatible and self-compatible species. Indeed, these results extend the rule of Lewis and Crowe (1958) that unilateral incompatibility is of universal occurrence regardlcss of the type of control of selfincompatibility. G. geniculata would appear to be of the SG type (Lewis and Crowe, l.c.) and the self-fertility therefore of ancient origin. This conclusion is given added support by the reduction in size of all floral parts in G. geniculata in comparison to those of G. oaxacana (Jones, Colden and Hunt, 1969; Hunt, 1972) and to the occurrence of cleistogamous flowers in the former species, both strong adaptations to inbreeding.

It is tempting to suggest that the self-compatibility in $G$. geniculata arose because of the change in chromosome number from diploid to tetraploid and hexaploid. This situation, although rare in monocotyledons (see below), is well known for diploid and tetraploid species of several members of the dicotyledons which possess a gametophytic incompatibility system (e.g. see Lewis, 1954). An increase in the level of ploidy leads to either partial or full self-compatibility because of allelic interaction in the pollen which results in both alleles failing to produce their effect. An hypothesis which explains the origin of self-compatibility in G. geniculata cannot, however, be erected on the basis of results in this study for two chief reasons. Firstly the relationship of the two species in the section Heterobasis although close is not simply one of a change in ploidy levels. External morphology including leaf and floral characters (Hunt, 1972) as well as anatomical features (Stant, 1973) clearly distinguish the species and although they are similar in both chromosome size and asymmetry of the chromosome complement, differences in karyotype morphology support their separation. Their distributions are also different. G. geniculata is distributed widely in lowland tropical America whilst $G$. oaxanaca is known only from one locality in the state of Oaxaca in Mexico (Hunt, 1972). It is highly unlikely from several points of view, therefore, that the polyploid arose directly from the diploid. Secondly polyploid species in the other section, Gibasis, of the genus are self-incompatible (Owens, unpub.) as arc the polyploid species of Tradescantia (Anderson and Sax, 1934; Annerstedt and Lundquist, 1967). Indeed the lack of allelic interaction in polyploid species appears to bc a characteristic of the Monocotyledons as a whole (Sagawa, 1958; Collins, 1961; Murray, 1974; Lundquist, 1975) and is thought to be a prerequisite for the dcvelopment of the two-locus gametophytic system found in the family Gramineae (Murray, 1974; Lundquist, 1975). This latter situation will be discussed more fully in a later publication.

Acknowledgments.-I would like to thank Dr Keith Jones and Dr Brian Murray for reading the manuscript and for useful comments and criticisms. I am also grateful to my colleagues in the Department of Cytology for helpful discussions. 


\section{REFERENCES}

ANDERSON, E. AND SAX, K. 1934. A cytological analysis of self-sterility in Tradescantia. Bot. Gaz., 95, 609-621.

ANNERSTEDT, 1., AND LUNDQUIST, A. 1967. Genetics of self incompatibility in Tradescantia paludosa (Commelinaceae). Hereditas, 58, 13-30.

BREWBAKeR, J. L. 1957. Pollen cytology and self-incompatibility systems in plants. $\mathcal{J}$. Hered., 48, 271-277.

BREWBAKER, J. L. 1967. The distribution and phylogenetic significance of binucleate and trinucleate pollen grains in the Angiosperms. Amer. F. Bot., 54, 1069-1083.

collins, J. L. 1961. The Pineapple: Botany, Cultivation and Utilisation. Interscience Publishers Inc., N.Y.

DE CREHU, G. 1968. Early testing of pollen stigma compatible relationships in $B$. oleracea by fluorescence. Brassica meeting of EUCARPIA, 34, September 1968.

HUNT, D. R. 1972. Gibasis oaxacana. Curtis's Bot. Mag., 179, t.624.

HUNT, D. R. 1975. American Commelinaceae II. Notes on Gibasis Ratin. Kew Bull., 30, 709-14.

JONES, K. 1974. Chromosome evolution by Robertsonian translocation in Gibasis (Commelinaceae). Chromosoma (Berl.), 45, 353-368.

JONES, K., AND COLDEN, C. 1968. The telocentric complement of Tradescantia micrantha. Chromosoma, 24, 135-157.

JONES, K., COLDEN, C., AND HUNT, D. R. 1969. Contribution to the cytotaxonomy of the Commelinaceae. 1. Tradescantia geniculata and its allies. Bot. F. Linn. Soc., 62, 205-221. JONES, K., AND JOPlING, c. 1972. Chromosomes and the classification of the Commelinaceae. Bot. J. Linn. Soc., 65 (2), 129-162.

JONES, K., AND KUKKONEN, I. 1971. The comparative cytology of some Cyanotis species. 7. Indian Bot. Soc. Golden Fubilee Volume, 50A, 332-339.

JONES, K., PAPES, D., AND HUNT, D. R. 1975. Contributions to the cytotaxonomy of the Commelinaceae. II. Further observations on Gibasis geniculata and its allies. Bot. 7 . Linn. Soc., 71, 145-166.

LEWIS, D. 1954. Comparative incompatibility in angiosperms and fungi. Advances in Genet., 6, 235-285.

LEWIS, D., AND CROWE, L. K. 1958. Unilateral interspecific incompatibility in flowering plants. Heredity, 12, 233-256.

LUNDQUIST, A. 1975. Complex self-incompatibility systems in angiosperms. Proc. R. Soc. Lond. B., 188, 235-245.

MURRAY, B. G. 1974. Breeding systems and floral biology in the genus Briza. Heredity, $33(2), 285-292$.

Rohweder, O. 1956. Die Farinosae in den Vegetation von El Salvador. Abh. Geb. Auslandskunde, 61 (C. 18).

sagawa, x. 1958. The production of polyploid Easter Lilies. I. Triploids. 7. Hered., 49, 194-198.

STANT, M. Y. 1973. Scanning electron microscopy of silica bodies and other epidermal features in Gibasis (Tradescantia) leaf. Bot. F. Linn. Soc., 66, 233-243. 